\title{
Vibrio superstes sp. nov., isolated from the gut of Australian abalones Haliotis laevigata and Haliotis rubra
}

Correspondence
Tomoo Sawabe
sawabe@fish.hokudai.ac.jp

\author{
Karin Hayashi, ${ }^{1}$ Jun Moriwaki, ${ }^{1}$ Tomoo Sawabe, ${ }^{1}$ Fabiano L. Thompson, ${ }^{2}$ \\ Jean Swings, ${ }^{2}$ Nicholas Gudkovs, ${ }^{3}$ Richard Christen ${ }^{4}$ and Yoshio Ezura ${ }^{1}$ \\ ${ }^{1}$ Laboratory of Microbiology, Graduate School of Fisheries Sciences, Hokkaido University, 3-1-1 \\ Minato-cho, Hakodate 041, Japan \\ ${ }^{2}$ Laboratory of Microbiology, University of Ghent, Ledeganckstraat 35, B-9000 Ghent, Belgium \\ ${ }^{3}$ CSIRO - Livestock Industries, Australian Animal Health Laboratory, 5 Portarlington Road, \\ Private Mail Bag 24, Geelong, Victoria 3220, Australia \\ ${ }^{4}$ Centre National de la Recherche Scientifique and Université de Nice Sophia-Antipolis, \\ Laboratoire Jean Maetz, Villefranche-sur-Mer F06230, France
}

Vibrio halioticoli and genetically related species, which are alginolytic, non-motile, fermentative marine bacteria, are abundant in the gut of Haliotis abalones in Japan and South Africa (Sawabe et al., 1995, 2002). Hypothesized roles of $V$. halioticoli include its contribution to the digestion of alginate, which is a major polysaccharide in Japanese kelps ingested by these animals, and its conversion into volatile short-chained fatty acids via fermentation (Sawabe et al., 2003). Nearly 80 species of abalone are known; they appear in offshore areas worldwide, but little is known about the presence of $V$. halioticoli-like bacteria in the gut of these molluscs. We recently isolated a set of five strains that were most similar phenotypically to $V$. halioticoli from the gut of

\footnotetext{
Abbreviations: FAFLP, fluorescent amplified fragment length polymorphism; ML, maximum-likelihood; MP, maximum-parsimony; $\mathrm{NJ}$, neighbour-joining.

The GenBank/EMBL/DDBJ accession numbers for the 16S rDNA sequences of Vibrio superstes are AF519806 (LMG 21319= B1-5), AY155582 (LMG 21320=B2-3), AY155583 (LMG $21321=$ G3-11), AY155584 (LMG 21322=G3-15) and AY155585 (LMG $21323^{\top}=\mathrm{G} 3-29^{\top}$ ).

Figures showing a full phylogenetic tree and a transmission electron micrograph of Vibrio superstes LMG $21323^{\top}$ are available as supplementary material in IJSEM Online.
}

Australian abalones (Haliotis laevigata and Haliotis rubra). DNA-DNA hybridization experiments, phenotypic characterization and phylogenetic and genetic analyses demonstrated that these strains represent a so far unknown species of the genus Vibrio.

Five strains of $V$. superstes sp. nov. [LMG 21319 (=IAM $15007=$ B1-5), LMG $21320(=$ IAM $15008=$ B2-3), LMG $21321(=\mathrm{G} 3-11)$, LMG $21322(=\mathrm{G} 3-15)$ and LMG $21323^{\mathrm{T}}$ $\left(=\mathrm{IAM} 15009^{\mathrm{T}}=\mathrm{G} 3-29^{\mathrm{T}}\right)$ ] were isolated from the gut of the Australian abalones $H$. laevigata and $H$. rubra. These were collected at the coastal area of Clifton Springs, Victoria, Australia, by scuba-diving in December 2000. Strains were cultured on ZoBell 2216E agar (Oppenheimer \& ZoBell, 1952) and stored at $-80^{\circ} \mathrm{C}$ in $10 \%$ glycerol.

The sequence of a $1400 \mathrm{bp}$ fragment of the $16 \mathrm{~S}$ rDNA gene of strains LMG 21319, LMG 21320, LMG21321, LMG 21322 and LMG $21323^{\mathrm{T}}$ was determined according to Sawabe et al. (1998) by using six sequencing primers $(24 \mathrm{~F}, 530 \mathrm{~F}$, $1100 \mathrm{~F}, 520 \mathrm{R}, 920 \mathrm{R}$ and 1540R). The $16 \mathrm{~S} \mathrm{rDNA}$ sequences of $V$. superstes and related species were selected from a database of more than 60000 already aligned bacterial $16 \mathrm{~S}$ rDNA sequences. Selection of sequences was done according to previous phylogenetic analyses of the entire database 


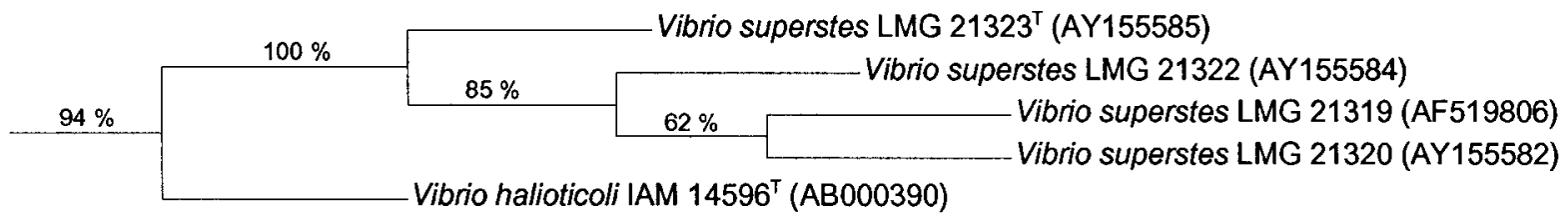

Fig. 1. Unrooted phylogenetic tree based on $16 \mathrm{~S}$ rDNA sequence data. This figure combines the results of three analyses, i.e. NJ, MP and ML. The topology shown was obtained by using NJ and 1000 bootstrap replications (shown above branches).

and BLAST searches against the latest EBI release. Phylogenetic trees were constructed by using three different methods [BIONJ, maximum-likelihood (ML) and maximumparsimony (MP)]. For neighbour-joining (NJ) analysis, distance matrices were calculated by using the Kimura two-parameter correction. BIONJ was done according to

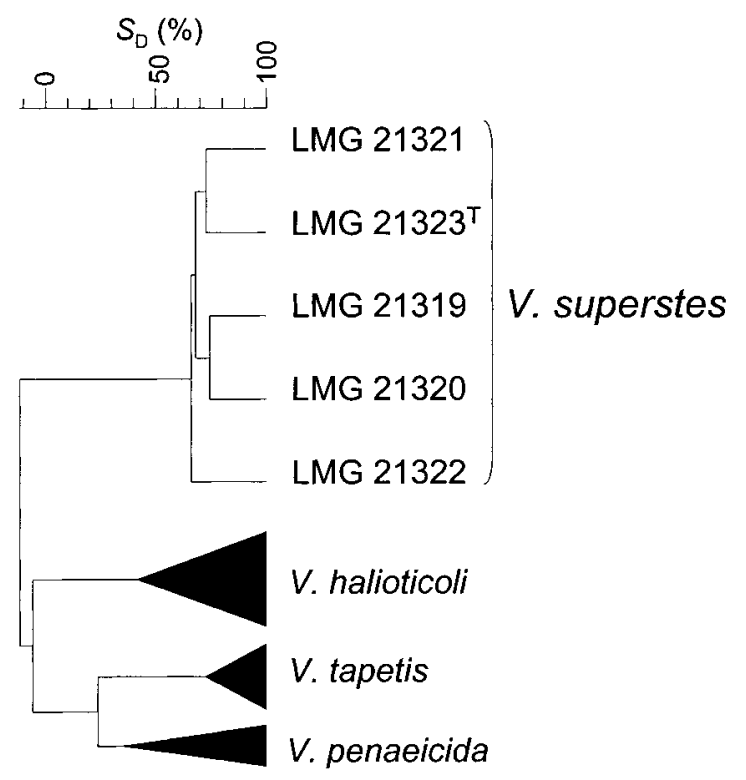

Fig. 2. Dendrogram of FAFLP patterns of the five novel Vibrio isolates from Australian abalone. V. halioticoli, Vibrio tapetis and Vibrio penaeicida were included as outgroups.
Gascuel (1997), ML and MP were from PHYLIP (Phylogeny Inference Package, version $3.573 \mathrm{c}$; distributed by J. Felsenstein, Department of Genetics, UW, Seattle, WA, USA). Because of close relationships, no evident homoplasy was detected and almost-entire sequences that corresponded to positions 47-1364 of the sequence of the type strain of $V$. superstes were used for the analysis (a short insertion in the Salinivibrio costicola sequence between positions 159 and 160 of $V$. superstes was excluded from the analysis). Phylogenetic trees were drawn by using NJPLOT (Perrière \& Gouy, 1996). The topology shown (Fig. 1) is that of the bootstrap tree, as it has been demonstrated that this topology is often better than that of a simple NJ or MP analysis (Berry \& Gascuel, 1996). There is no distance bar in Fig. 1 as it would be meaningless because: (i) distances are corrected (see above) and (ii) this is a bootstrap tree.

Fluorescent amplified fragment length polymorphism (FAFLP) analysis was performed as described previously (Thompson et al., 2001; Sawabe et al., 2002). Clustering of the patterns was done by using the Dice coefficient $\left(S_{\mathrm{D}}\right)$ and the Ward algorithm (Sneath \& Sokal, 1973).

DNA of bacterial strains was prepared by the procedure of Marmur (1961). DNA G + C contents were determined by HPLC (Tamaoka \& Komagata, 1984). DNA-DNA hybridization experiments were performed in microdilution wells by using a fluorometric direct-binding method described by Ezaki et al. (1988, 1989).

In total, 78 phenotypic characteristics, including alginase

Table 1. DNA relatedness between Vibrio superstes and Vibrio halioticoli

\begin{tabular}{|lccc|}
\hline Strain & $\begin{array}{c}\text { G+C content } \\
(\mathbf{m o l} \%)\end{array}$ & \multicolumn{2}{c|}{ Reassociation (\%) with biotinylated DNA from: } \\
\cline { 3 - 4 } & & & \\
& & & \\
& & & \\
V. superstes LMG 21323 & V. halioticoli IAM 14596 & \\
LMG 21319 & $48 \cdot 0$ & $75 \cdot 3$ & $29 \cdot 9$ \\
LMG 21320 & $48 \cdot 9$ & $87 \cdot 4$ & $28 \cdot 5$ \\
LMG 21321 & $48 \cdot 9$ & $94 \cdot 4$ & $24 \cdot 3$ \\
LMG 21322 & $48 \cdot 3$ & $100 \cdot 0$ & $25 \cdot 7$ \\
LMG 21323 & $48 \cdot 6$ & $12 \cdot 9$ & $22 \cdot 4$ \\
V. halioticoli IAM 14596 & & & $100 \cdot 0$ \\
\hline
\end{tabular}


activity, were determined by standard methods (Leifson, 1963; Hidaka \& Sakai, 1968; West et al., 1977; Ostle \& Holt, 1982; Baumann \& Schubert, 1984; Holt et al., 1994). These phenotypic characterizations were done at $20^{\circ} \mathrm{C}$.

The results of our phylogenetic analysis showed clearly that the strains belonged to the $\gamma 3$ subgroup, phylum Proteobacteria (Garrity \& Holt, 2001) (see Supplementary Fig. A in IJSEM Online). The closest phylogenetic neighbour of the five Australian abalone strains is $V$. halioticoli (Fig. 1). The five strains of $V$. superstes had high levels of 16S rDNA sequence similarity to each other, i.e. 99.7-99.9\%, and $98 \cdot 3 \%$ similarity to $V$. halioticoli IAM $14596^{\mathrm{T}}$. Similarity levels of $<97 \cdot 3 \%$ were found with other Vibrio species.

The five strains had FAFLP patterns that consisted of $90 \pm 10$ fragments (minimum, 80; maximum, 108) and mutual similarity of at least $64 \cdot 6 \%$ (Fig. 2). V. superstes showed pattern similarities of $<50 \%$ to other Vibrio species, which shows clearly that this novel species is different from other vibrios (Thompson et al., 2001). The FAFLP results are supported by our DNA-DNA hybridization experiments, which showed that the five strains of V. superstes (LMG 21319, LMG 21320, LMG 21321, LMG 21322 and LMG $21323^{\mathrm{T}}$ ) were conspecific strains that were clearly separated from $V$. halioticoli (Table 1).

The five Australian abalone strains have the main phenotypic features of the genus Vibrio (except for the absence of flagella). The strains are non-motile, Gram-negative and fermentative (Sawabe et al., 1998). No flagellated cells were observed by transmission electron microsscopy, but short tubular projections were observed in $V$. superstes cells, similar to those around Vibrio campbellii cells [as reported by Allen \& Baumann (1971)] (see Supplementary Fig. B in IJSEM Online). The function of these tubular projections has never been clarified (Allen \& Baumann, 1971). These strains required salt for growth, did not accumulate poly$\beta$-hydroxybutyrate and were oxidase-positive (Table 2). No peritrichous cells were observed when the strains were cultivated on solid media. Other phenotypic features of $V$. superstes are shown in Table 2. The five abalone isolates were most similar phenotypically to $V$. halioticoli IAM $14596^{\mathrm{T}}$, although the strains differed by 17 out of 78 traits tested (Table 2).

Despite the close phylogenetic relationship between $V$. superstes and $V$. halioticoli, $V$. superstes occurs in rather small populations, the size of which range from 0 to $20 \%$ in the gut of Australian abalones (data not shown). Compared to the abundant populations of $V$. halioticoli and its speculated symbiotic contribution to the conversion of alginate to acetic acid in the gut of Japanese and South African abalones (Sawabe et al., 2003), V. superstes may not be able to form such associations with Australian abalones because the major food of Australian abalones is red algae (Foale \& Day, 1992). Differences in feeding behaviour of host abalones may affect the microflora of the gut microbial ecosystem and select for biochemical traits of these
Table 2. Phenotypic characteristics for distinguishing Vibrio superstes from previously described alginolytic Vibrio species

Species/strains: 1, V. superstes LMG 21319-LMG $21323^{\mathrm{T}} ; 2, \quad V$. halioticoli IAM $14596^{\mathrm{T}}$; 3, Vibrio pelagius biovar 1 ATCC $25916^{\mathrm{T}}$. + , Positive; -, negative; $\mathrm{V}+$, variable (type strain is positive); $\mathrm{V}-$, variable (type strain is negative). All species are negative for the following characteristics: pigmentation, swarming, poly- $\beta$ hydroxybutyrate accumulation, luminescence, growth at 4 and $40^{\circ} \mathrm{C}$, amylase, gelatinase, chitinase, agarase, gas production from D-glucose, acetoin production, lysine decarboxylase, arginine dehydrolase, ornithine decarboxylase, acid from L-arabinose, inositol and L-rhamnose, requirement for organic growth factors, utilization of D-sorbitol, L-tyrosine, meso-erythritol, L-arabinose, citrate, DL-malate, $\delta$-aminovalerate and aconitate. All species are positive for the following characteristics: $\mathrm{Na}^{+}$requirement, growth at 15 and $30^{\circ} \mathrm{C}$, oxidase, catalase, alginase, nitrate reduction, $\mathrm{O} / 129$ sensitivity, methyl red test, growth on TCBS (thiosulfate/citrate/bile salts/sucrose) agar, growth in $3 \% \mathrm{NaCl}$, acid from D-glucose, D-mannitol and maltose, utilization of alginate, D-fructose, Dglucose, maltose, D-mannitol, D-glucosamine, $\mathrm{N}$-acetylglucosamine, fumarate and succinate. All species are fermentative in the oxidationfermentation test.

\begin{tabular}{|c|c|c|c|}
\hline Characteristic & $1(n=5)$ & 2 & 3 \\
\hline Motility & - & - & + \\
\hline Growth at $37^{\circ} \mathrm{C}$ & - & - & + \\
\hline \multicolumn{4}{|l|}{ Production of: } \\
\hline Lipase & - & - & + \\
\hline Indole & - & + & - \\
\hline ONPG test & - & + & + \\
\hline \multicolumn{4}{|l|}{ Growth in: } \\
\hline $1 \% \mathrm{NaCl}$ broth & - & - & + \\
\hline $6 \% \mathrm{NaCl}$ broth & - & - & + \\
\hline \multicolumn{4}{|l|}{ Acid from: } \\
\hline Sucrose & - & - & + \\
\hline D-Sorbitol & - & - & + \\
\hline \multicolumn{4}{|l|}{ Utilization of: } \\
\hline D-Mannose & + & - & + \\
\hline Sucrose & + & - & + \\
\hline D-Gluconate & + & - & + \\
\hline Glycerol & - & + & + \\
\hline 2-Oxoglutarate & - & - & + \\
\hline D-Galactose & + & - & + \\
\hline Cellobiose & + & - & - \\
\hline Melibiose & + & - & - \\
\hline Lactose & + & - & - \\
\hline D-Glucuronate & + & - & - \\
\hline Trehalose & $\mathrm{v}+$ & - & + \\
\hline Putrescine & $\mathrm{v}-$ & - & + \\
\hline$\gamma$-Aminobutyrate & + & - & + \\
\hline Acetate & + & - & + \\
\hline Pyruvate & - & - & + \\
\hline Propionate & $\mathrm{v}+$ & - & + \\
\hline L-Glutamate & + & - & + \\
\hline D-Xylose & + & - & - \\
\hline
\end{tabular}


symbiotic vibrios. Major phenotypic traits of $V$. superstes differed from those of $V$. halioticoli in that the former was positive for use of 14 carbon compounds (Table 2). $V$. superstes may have acquired the ability to assimilate multiple carbon compounds to survive in the gut of the Australian abalone.

In conclusion, our polyphasic study demonstrated clearly that the five abalone isolates represent a so far undescribed species of the genus Vibrio, for which we propose the name Vibrio superstes sp. nov. The name $V$. superstes, which means survivor, has been chosen in this respect. Global whole-genome analyses may clarify the evolutionary history of $V$. superstes and $V$. halioticoli. Studies on the ecology of $V$. superstes are under way in order to better understand its interactions in the gut of marine herbivores, particularly abalones.

\section{Description of Vibrio superstes sp. nov.}

Vibrio superstes (su.per'stes. L. masc. adj. superstes remaining alive after another's death, outliving, surviving).

Gram-negative, facultatively anaerobic, non-motile and non-flagellated. Cells in ZoBell $2216 \mathrm{E}$ broth are rodshaped with rounded ends $(0 \cdot 6-0 \cdot 8 \times 1 \cdot 2-1 \cdot 3 \mu \mathrm{m})$. No endospores or capsules are formed. Flagellation is not observed when the organism is cultivated on solid and/or in liquid media. Colonies on ZoBell 2216E agar are beige, circular, smooth and convex with entire edges. Sodium ions are essential for growth. Mesophilic and neutrophilic chemo-organotroph: grows between 15 and $30^{\circ} \mathrm{C}$. No growth occurs at $40^{\circ} \mathrm{C}$. Positive for acid production from glucose, nitrate reduction, hydrolysis of alginate, oxidase and catalase and assimilation of D-mannose, sucrose, D-gluconate, D-galactose, cellobiose, melibiose, lactose, D-glucuronate, trehalose, $\gamma$-aminobutyrate, acetate, propionate, L-glutamate, D-xylose, D-fructose, maltose, Dglucosamine, $\mathrm{N}$-acetylglucosamine, D-mannitol, fumarate, succinate, $\mathrm{D}$-glucose and alginate. The following tests are negative: gas production from glucose, acetoin production, lysine decarboxylase, arginine dehydrolase, ornithine decarboxylase, indole production, $\beta$-galactosidase test, luminescence, pigmentation, requirement for organic growth factors, hydrolysis of starch, gelatin, chitin, Tween 80 and agar, accumulation of poly- $\beta$-hydroxybutyrate, assimilation of D-sorbitol, glycerol, citrate, meso-erythritol, DL-malate, 2-oxoglutarate, putrescine, $\delta$-aminovalerate, pyruvate, L-tyrosine, aconitate and L-arabinose. DNA $\mathrm{G}+\mathrm{C}$ content is $48 \cdot 0-48 \cdot 9 \mathrm{~mol} \%$.

The type strain is LMG $21323^{\mathrm{T}}=\mathrm{IAM} 15009^{\mathrm{T}}$. The bacterium was isolated from the gut of the Australian abalones Haliotis rubra and H. laevigata.

\section{Acknowledgements}

This work was supported by Grants-in-Aid for Scientific Research from the Ministry of Education, Science and Culture of Japan (nos 09460081 and 13760134) and F. L.T. has a PhD scholarship (no. 2008361/98-6) from Conselho Nacional de Desenvolvimento Científico e Tecnológico (CNPq), Brazil. J.S. acknowledges grants from the Fund for Scientific Research (FWO), Belgium.

\section{References}

Allen, R. D. \& Baumann, P. (1971). Structure and arrangement of flagella in species of the genus Beneckea and Photobacterium fischeri. J Bacteriol 107, 295-302.

Baumann, P. \& Schubert, R. H. W. (1984). Vibrionaceae. In Bergey's Manual of Systematic Bacteriology, vol. 1, pp. 516-550. Edited by N. R. Krieg \& J. G. Holt. Baltimore: Williams \& Wilkins.

Berry, V. \& Gascuel, O. (1996). On the interpretation of bootstrap trees: appropriate threshold of clade selection and induced gain. Mol Biol Evol 13, 999-1011.

Ezaki, T., Hashimoto, Y., Takeuchi, N., Yamamoto, H., Liu, S.-L., Miura, H., Matsui, K. \& Yabuuchi, E. (1988). Simple genetic method to identify viridans group streptococci by colorimetric dot hybridization and fluorometric hybridization in microdilution wells. J Clin Microbiol 26, 1708-1713.

Ezaki, T., Hashimoto, Y. \& Yabuuchi, E. (1989). Fluorometric deoxyribonucleic acid-deoxyribonucleic acid hybridization in microdilution wells as an alternative to membrane filter hybridization in which radioisotopes are used to determine genetic relatedness among bacterial strains. Int J Syst Bacteriol 39, 224-229.

Foale, S. \& Day, R. W. (1992). Recognizability of algae ingested by abalone. Aust J Mar Freshw Res 43, 1331-1338.

Garrity, G. M. \& Holt, J. G. (2001). The road map to the Manual. In Bergey's Manual of Systematic Bacteriology, 2nd edn, vol. 1, pp. 119-166. Edited by D. R. Boone, R. W. Castenholz \& G. M. Garrity. New York: Springer-Verlag.

Gascuel, O. (1997). BIONJ: an improved version of the NJ algorithm based on a simple model of sequence data. Mol Biol Evol 14, 685-695.

Hidaka, T. \& Sakai, M. (1968). Comparative observation of inorganic salt requirement of the marine and terrestrial bacteria. Bull Misaki Mar Biol Inst Kyoto Univ 12, 125-149.

Holt, J. G., Krieg, N. R., Sneath, P. H. A., Staley, J. T. \& Williams, S. T. (1994). Facultatively anaerobic Gram-negative rods. Subgroup 2: family Vibrionaceae. In Bergey's Manual of Determinative Microbiology, 9th edn, pp. 190-253. Baltimore: Williams \& Wilkins.

Leifson, E. (1963). Determination of carbohydrate metabolism of marine bacteria. J Bacteriol 85, 1183-1184.

Marmur, J. (1961). A procedure for the isolation of deoxyribonucleic acid from microorganisms. J Mol Biol 3, 208-218.

Oppenheimer, C. H. \& ZoBell, C. E. (1952). The growth and viability of sixty-three species of marine bacteria as influenced by hydrostatic pressure. J Mar Res 11, 10-18.

Ostle, A. G. \& Holt, J. G. (1982). Nile blue A as a fluorescent stain for poly- $\beta$-hydroxybutyrate. Appl Environ Microbiol 44, 238-241.

Perrière, G. \& Gouy, M. (1996). WWW-Query: an on-line retrieval system for biological sequence banks. Biochimie 78, 364-369.

Sawabe, T., Oda, Y., Shiomi, Y. \& Ezura, Y. (1995). Alginate degradation by bacteria isolated from the gut of sea urchins and abalones. Microb Ecol 30, 193-202.

Sawabe, T., Sugimura, I., Ohtsuka, M., Nakano, K., Tajima, K., Ezura, Y. \& Christen, R. (1998). Vibrio halioticoli sp. nov., a nonmotile alginolytic marine bacterium isolated from the gut of the abalone Haliotis discus hannai. Int J Syst Bacteriol 48, 573-580.

Sawabe, T., Thompson, F. L., Heyrman, J. \& 7 other authors (2002). Fluorescent amplified fragment length polymorphism and repetitive 
extragenic palindrome-PCR fingerprinting reveal host-specific genetic diversity of Vibrio halioticoli-like strains isolated from the gut of Japanese abalone. Appl Environ Microbiol 68, 4140-4144.

Sawabe, T., Setoguchi, N., Inoue, S., Tanaka, R., Ootsubo, M., Yoshimizu, M. \& Ezura, Y. (2003). Acetic acid production of Vibrio halioticoli from alginate: a possible role for establishment of abaloneV. halioticoli association. Aquaculture 219, 671-679.

Sneath, P. H. A. \& Sokal, R. R. (1973). Numerical Taxonomy. San Francisco: W. H. Freeman.
Tamaoka, J. \& Komagata, K. (1984). Determination of DNA base composition by reverse-phase high-performance liquid chromatography. FEMS Microbiol Lett 25, 125-128.

Thompson, F. L., Hoste, B., Vandemeulebroecke, K. \& Swings, J. (2001). Genomic diversity amongst Vibrio isolates from different sources determined by fluorescent amplified fragment length polymorphism. Syst Appl Microbiol 24, 520-538.

West, M., Burdash, N. M. \& Freimuth, F. (1977). Simplified silverplating stain for flagella. J Clin Microbiol 6, 414-419. 